\title{
RESEARCH NOTE \\ Chemical and physical characterization of Opuntia spp. seeds grown in Hidalgo State, Mexico
}

\author{
Francisco Prieto-García 1 , Judith Prieto Méndez², Otilio A. Acevedo \\ Sandoval $^{2}$, Roberto A. Canales Flores ${ }^{1}$, and Yolanda Marmolejo Santillán ${ }^{1}$ \\ ${ }^{1}$ Área académica de Química, ${ }^{2}$ Instituto de Ciencias Agropecuarias. Universidad Autónoma del Estado de \\ Hidalgo. Carretera Pachuca - Tulancingo Km. 4.5 C.P. 42076. Colonia Carboneras, Mineral de la Reforma \\ Hidalgo. Pachuca, Hidalgo, Mexico.
}

\begin{abstract}
F. Prieto-García, J. Prieto Méndez, O.A. Acevedo Sandoval, R. A. Canales Flores, and Y. Marmolejo Santillán. 2016. Chemical and physical characterization of seeds of Opuntia spp. grown in Hidalgo State, Mexico. Cien. Inv. Agr. 43(1):143-150. Nopal fruits (Opuntia spp.) represent a valuable food in various Latin America countries. Typically, the seeds are discarded. However, they could contain basic components that might enable their use as a nutritional supplement or as another product convenient for the food industry. The objective of this paper was to perform a physical and chemical characterization of the seeds of three species of Opuntia (O. Heliabravoana, O. Xoconostle, and O. ficus-indica) to provide data that will help determine their potential use. Fruits were collected in different municipalities of Hidalgo State, Mexico; its seeds were extracted, dried, and analyzed. The results reveal that, except for small differences, the seeds had similarity in the physical characteristics of density and hardness to abrasion. Due to its relative size and volume, the seed of O. ficus-indica was 2.37 times more voluminous than the smallest seed (O. heliabravoana) and 1.50 times more voluminous than the $O$. xoconostle seed. The size and morphologies of grains were similar among the species. Due to their relatively high content of oil, fibers, starches and carbohydrates, the seed may represent a nutritional food they result interesting to be evaluated as nutritious food. However, in all the seeds, a substantial amount of lead was found, which is a metal that is non-desirable in any food.
\end{abstract}

Key words: Cactaceae, electron microscope, heavy metals, particle size, Prickly pear, proximal analysis.

\section{Introduction}

The cacti family consists of approximately 2000 species distributed in dry desert climate locations,

Received April 22, 2015. Accepted January 17, 2016. Corresponding author: prietog@uaeh.edu.mx primarily in Central and South America. The geographical conditions of Mexico, with its distinctive topography, have favored the diversification of these plants, resulting in areas of substantial biological wealth. In Mexico, approximately 100 species (Bravo-Holly, 1991; Ojeda et al., 2010) are recognized, a substantial number of which are endemic. 
Widely used as food, most cacti are exploited as food primarily for their fruit and leaves. The cactus and its fruit, the tuna, are also part of the diet of many animals.

In dry and windy locations, cacti are used to hold the soil and prevent erosion by the rains that normally occur intensively at certain times of year. This use is well suited to crops that are planted in the form of terraces.

The fruits of certain species of Opuntia, with high content of ascorbic acid, are referred to as xoconostles, or acidic cactus pears. They possess substantial economic potential due to their many uses as a vegetable, seasoning, fresh fruit, a crystallized sweet, and forage and for their possible medicinal properties (Scheinvar, 1999; Terán et al., 2015).

However, despite the different uses of the fruits of Opuntia, the question whether their seeds have food or agribusiness utility has not been studied.

The aim of this paper was to characterize the physical and chemical composition of the seeds of three Mexican species of Opuntia grown in Hidalgo State (Opuntia heliabravoana, O. xoconostle and $O$. ficus indica) to provide data that will help determine their potential use.

\section{Materials and methods}

\section{Samples: Collection and preparation}

Representative samples of seeds of the three species were extracted from cultured fruit in different municipalities of Hidalgo State. The extracted seeds were cleaned of all extraneous matter or pulp and dried at atmospheric conditions in plastic trays. Subsequently, the seeds were manually selected to be as homogeneous as possible in terms of physical structure. An approximately $150 \mathrm{~g}$ sample of previously dried seeds of each species were subjected to grinding and passed through a Tyller $200 \mathrm{~mm}$ sieve.

\section{Physical and chemical analysis}

Prior to grinding, the following parameters of the seeds were established through physical analysis (AOAC, 1995; Mexican Standard, 2003): moisture content, ash content, density per hectoliter weight and thousand kernel weight, flotation index (expressed as the percentage of floating grains), abrasive hardness (expressed as a percentage of weight lost by abrasion after fivefold rubbing over $23 \mathrm{~cm}$ of No. 100 sandpaper) and unit volume.

Fractions were ground into fine powder and subjected to the following chemical determinations (AOAC, 1995): total fat, protein, crude fiber aggregate, and the amount of sodium, potassium, calcium, magnesium, iron, and zinc metals. The sugars were determined according Ödön and Tirso (1985) and BOE (English: Spanish Official Gazette) (1988). Total carbohydrates (\% TCH) were obtained by difference from the following expression (Pere, 1999, White et al., 2000):

$\% \mathrm{TCH}=100-\mathrm{SA}$
$\mathrm{SA}=\% \mathrm{H}_{2} \mathrm{O}+\%$ protein $+\%$ fibers $+\%$ fat $+\%$ ash

In parallel, estimated percentages of total starch were obtained using the following calculation (White et al., 2000):

$\%$ Total starch $=\%$ TCH - \% TRS

$\mathrm{TCH}=$ total carbohydrates and TRS $=$ total reducing sugars.

\section{Particle analysis}

The particle size distribution and the starch content of the seeds were analyzed. To this end, the starch granules were separated by grinding, cold-water suspension and subsequent centrifuge separation. The settled solids (i.e., not cold-water soluble starches) were re-suspended in deionized water and analyzed using a laser diffraction particle size analyzer (Beckman Coulter, model LS 13-320). The morphology of the particles was evaluated 
by scanning electron microscopy (SEM) (Jeol, model JSM-6300).

Powder samples were placed in the sample holder after being coated with gold. A Desk II model was used. We worked at $15 \mathrm{KV}$, at equal distances from the workpiece and under $2000 \mathrm{X}$ magnification.

\section{Statistical analysis}

Inferential statistical analysis was performed, and significant differences were determined using Tukey's test.

\section{Results and discussion}

\section{Physical analysis}

The results of the physical characterization are shown in Table 1 . The table shows that $O$. heliabravoana had the highest values of density per hectoliter weight (DPH), which agrees with the values of greater hardness or resistance to abrasion and the smaller volume of the seed. This outcome indicates that the structure is robust and compact, which suggests that the seed is slightly porous.
O. xoconostle had the highest density value for thousand kernel weight (DVTK), which agrees with the lower abrasion resistance and lower density by flotation index (DFI). This outcome indicates that these seeds are softer, heavier in their relative masses and less porous due to the low DFI value. Opuntia ficus-indica is lighter (lower values of DPH and DVTK), soft, and the most porous of the three species. It was 2.37 times bulkier than $O$. heliabravoana and 1.50 times more voluminous than $O$. xoconostle.

\section{Proximate analysis}

The results of the proximate analyses, including sugars and starches, are shown in Tables 2 and 3. It can be observed that the three species have similar levels of moisture and ash content. The latter parameter is associated with the level of metals that the seeds contain. Similarly, the total crude fiber content and carbohydrates content of the seeds were similar.

The results of the proximate analyses, including sugars and starches, are shown in Tables 2 and 3. It can be observed that the three species have similar levels of moisture and ash content. The

Table 1. Physical parameters of the grains or seeds of three species of Opuntia (mean values and dispersion measure).

\begin{tabular}{lccccc}
\hline Species & DPH & DVTK & DFI & HD & Vol \\
\hline O. heliabravoana & & & & & \\
Average & $65.29 \mathrm{a}$ & $17.03 \mathrm{~b}$ & $14.80 \mathrm{~b}$ & $11.43 \mathrm{a}$ & 12.13 \\
C.V. $(\%)$ & 1.30 & 1.48 & 12.72 & 10.83 & 8.89 \\
O. xoconostle & & & & \\
Average & $64.22 \mathrm{a}$ & $29.19 \mathrm{a}$ & $6.80 \mathrm{c}$ & $7.42 \mathrm{~b}$ & $19.16 \mathrm{~b}$ \\
C.V. (\%) & 1.42 & 4.55 & 14.61 & 13.71 & 5.14 \\
O. ficus-indica & & & & \\
Average & $55.97 \mathrm{~b}$ & $13.43 \mathrm{c}$ & $23.21 \mathrm{a}$ & $7.59 \mathrm{~b}$ & $28.70 \mathrm{a}$ \\
CV $(\%)$ & 4.77 & 7.82 & 8.71 & 5.31 & 11.36 \\
\hline
\end{tabular}

DPH: density per hectoliter weight; DVTK: density value for thousand kernel weight; DFI: density by flotation index; HD: hardness abrasion; Vol: volume; CV: coefficient of variation.

The various letters in the columns indicate significant differences (Tukey $\mathrm{P} \leq 0.05$ ). 
latter parameter is associated with the level of metals that the seeds contain. Similarly, the total crude fiber content and carbohydrates content of the seeds were similar.

All three species have significant fat percentages, as exemplified by the species $O$. xoconostle, which exhibited the highest values. If it is found that the fat types are not potentially harmful to human health, the high carbohydrate and fat content indicate that the seeds could be used to develop a food supplement (Dendy and Dobraszczyk, 2004). However, because the protein content of the seeds is low, their potential for food use may be limited.

Regarding the estimated starch content in the three species, Table 3 shows that the highest values of reducing sugars and sucrose were present in $O$. xoconostle, which could be expected, given that the fruits of this species are consumed as food, primarily in the form of prepared sweets or des- serts. Likewise, significant starch content was observed in all three species.

\section{Metal analysis}

The total concentrations of metals bioaccumulated in the seeds of the three studied species are shown in Table 4. Regarding essential metal elements, lower values of calcium and magnesium were observed in O. xoconostle than in O. heliabravoana and $O$. ficus-indica. This outcome appears to reflect the origin of the metals in dolomitic soils (Borrego and Burgos, 1986).

Regarding trace-element content, it should be noted that zinc was not detected in any sample, which may indicate a deficit of this element in these soils or little bioaccumulation in these types of seed. One can observe the absence of detectable amounts of toxic elements, such as arsenic, mercury and cadmium. Chromium was

Table 2. Proximate analysis of the grain or seeds of three species of Opuntia (\%) (standard deviation in parentheses).

\begin{tabular}{lccccc}
\hline Specie & Moisture & Ash & Fat & Total fiber & Protein \\
\hline O. heliabravoana & $3.97(0.02) \mathrm{a}$ & $0.95(0.06) \mathrm{a}$ & $16.99(0.57) \mathrm{b}$ & $3.02(0.11) \mathrm{a}$ & $2.10(0.09) \mathrm{a}$ \\
O. xoconostle & $4.09(0.19) \mathrm{a}$ & $1.03(0.11) \mathrm{a}$ & $19.24(0.45) \mathrm{a}$ & $2.56(0.22) \mathrm{b}$ & $0.64(0.02) \mathrm{b}$ \\
O. ficus-indica & $3.55(0.09) \mathrm{a}$ & $1.01(0.08) \mathrm{a}$ & $17.22(0.46) \mathrm{b}$ & $2.66(0.14) \mathrm{b}$ & $0.97(0.01) \mathrm{b}$ \\
\hline
\end{tabular}

The various letters in the columns indicate significant differences (Tukey $\mathrm{P} \leq 0.05$ ).

Table 3. Analysis of sugars and starches in the grains or seeds of three Opuntia species (\%) (standard deviation in parentheses).

\begin{tabular}{lcccc}
\hline Specie & Total carbohydrates $(\mathrm{TCH})$ & Total reducing sugars (TRS) & Sucrose & Starches \\
\hline O. heliabravoana & $72.97(0.80) \mathrm{a}$ & $3.42(0.01) \mathrm{c}$ & $0.70(0.02) \mathrm{c}$ & $68.85(0.83) \mathrm{a}$ \\
O. xoconostle & $72.62(0.76) \mathrm{a}$ & $5.30(0.49) \mathrm{a}$ & $1.08(0.07) \mathrm{a}$ & $66.24(1.32) \mathrm{b}$ \\
O. ficus-indica & $74.68(0.56) \mathrm{a}$ & $4.16(0.13) \mathrm{b}$ & $0.85(0.02) \mathrm{b}$ & $69.67(0.71) \mathrm{a}$ \\
\hline
\end{tabular}

The various letters in the columns indicate significant differences (Tukey $\mathrm{P} \leq 0.05$ ).

Table 4. Essential and toxic metal content of the grain or seeds of three species of Opuntia $\left(\mathrm{mg} \mathrm{kg}^{-1}\right)$.

\begin{tabular}{lccccccccccc}
\hline Species & $\mathrm{Al}$ & $\mathrm{Cd}$ & $\mathrm{Ca}$ & $\mathrm{Cr}$ & $\mathrm{Pb}$ & $\mathrm{Mg}$ & $\mathrm{K}$ & $\mathrm{Na}$ & $\mathrm{Zn}$ & $\mathrm{As}$ & $\mathrm{Hg}$ \\
\hline O. heliabravoan & $7.32 \mathrm{a}$ & $<0.003$ & $809.82 \mathrm{a}$ & $<0.005$ & $70.79 \mathrm{a}$ & $2159.5 \mathrm{ab}$ & $223.2 \mathrm{ab}$ & $4.70 \mathrm{a}$ & $<0.001$ & $<0.004$ & $<0.002$ \\
O. xoconostle & $5.56 \mathrm{~b}$ & $<0.003$ & $251.49 \mathrm{c}$ & $<0.005$ & $43.99 \mathrm{~b}$ & $2990.8 \mathrm{a}$ & $178.6 \mathrm{a}$ & $3.31 \mathrm{bc}$ & $<0.001$ & $<0.004$ & $<0.002$ \\
O. ficus-indica & $2.48 \mathrm{c}$ & $<0.003$ & $736.44 \mathrm{~b}$ & $8.01 \mathrm{a}$ & $21.35 \mathrm{c}$ & $1431.2 \mathrm{c}$ & $239.7 \mathrm{a}$ & $3.63 \mathrm{~b}$ & $<.001$ & $<0.004$ & $<0.002$ \\
\hline
\end{tabular}

The various letters in the columns indicate significant differences (Tukey $\mathrm{P} \leq 0.05$ ). 
only observed in the species $O$. ficus indica in values below the permitted standards for seeds and grains (regulations Argentina, 2004). However, the lead content observed in the three species is considered high, particularly in O. heliabravoana. Thus, it is not surprising that in the parts of the fruit that are typically consumed (i.e., the pulp and rind) the lead content could be even more significant and become hazardous.

Lead can originate in the soil in which these species are grown or the water that is used to irrigate them. In this sense, Prieto et al. (2005a) reported that significant bioaccumulated arsenic concentrations were found in crops that have been harvested in areas with significant levels of this element in the soil and irrigation water.

\section{Particle size and morphology}

The analysis results for the particle size distribution of the granules of starch contained in the seeds of these species are shown in Figure 1a, b and c. The average sizes range from 23.81 to $55.13 \mathrm{~mm}$. Thus, the shapes and sizes of the starch granules are similar to those of cereal grains.

In this regard, it is noted that the species $O$. xoconostle has the largest granules and that the granules of $O$. heliabravoana exhibit the smallest diameter. However, both species display substantial variability in granule size distribution compared with $O$. ficus-indica.

The particle size distribution curves for the starches contained in the seeds of these species resemble those for beans or grains, such as wheat, rice and corn (Prieto et al., 2005b; Prieto et al., 2008). The range of variation in particle size is also similar to that reported by these authors for rice grains and wheat.

The morphology of the particles is shown in the microphotographs of Figure 2a, b and c. The particle sizes indicated in Figure 1 are similar
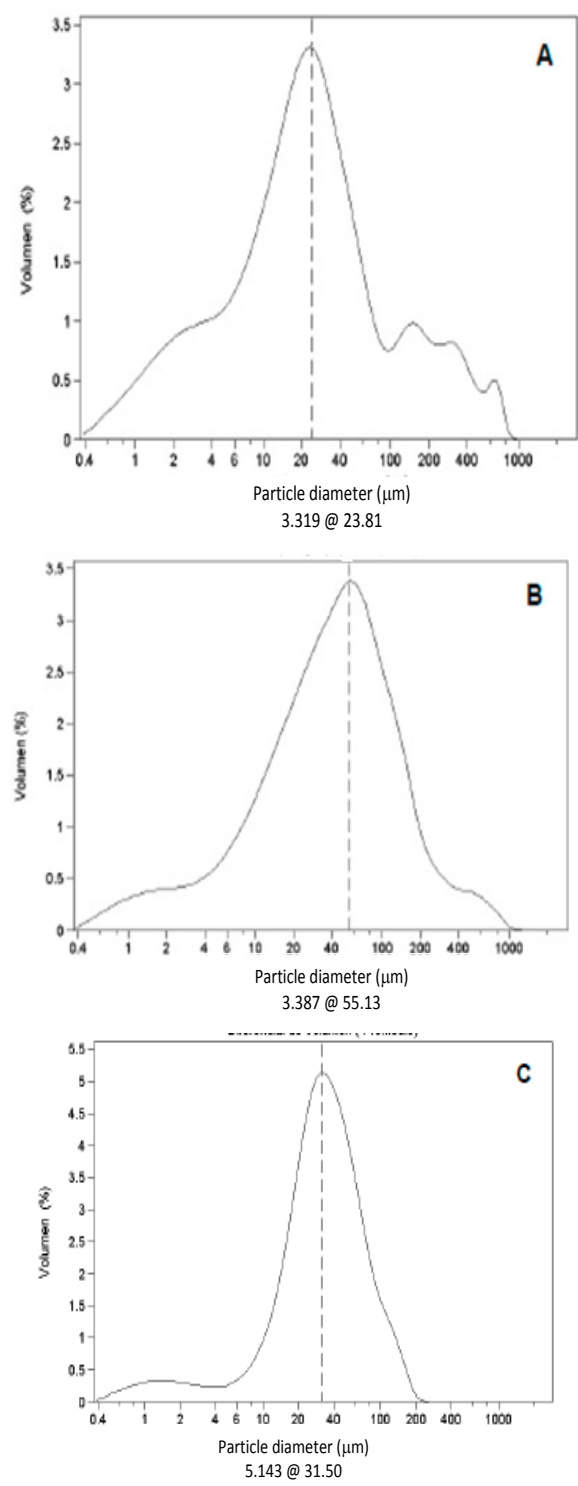

Figure 1. Distribution and particle size in the grains or seeds of three species of Opuntia. A) O. heliabravoana, B) $O$. xoconostle, and C) O. ficus-indica.

to those indicated in the photomicrographs. It can be observed that the structures in the form of granules are starches and correspond to those reported by several authors for other grains (Sharp, 1987; White et al., 2000; Prieto et al., 2005b).

Additionally, in the figures, clear filamentous structures can be observed in O. heliabravoana, $O$. xoconostle and $O$. ficus-indica. These structures 

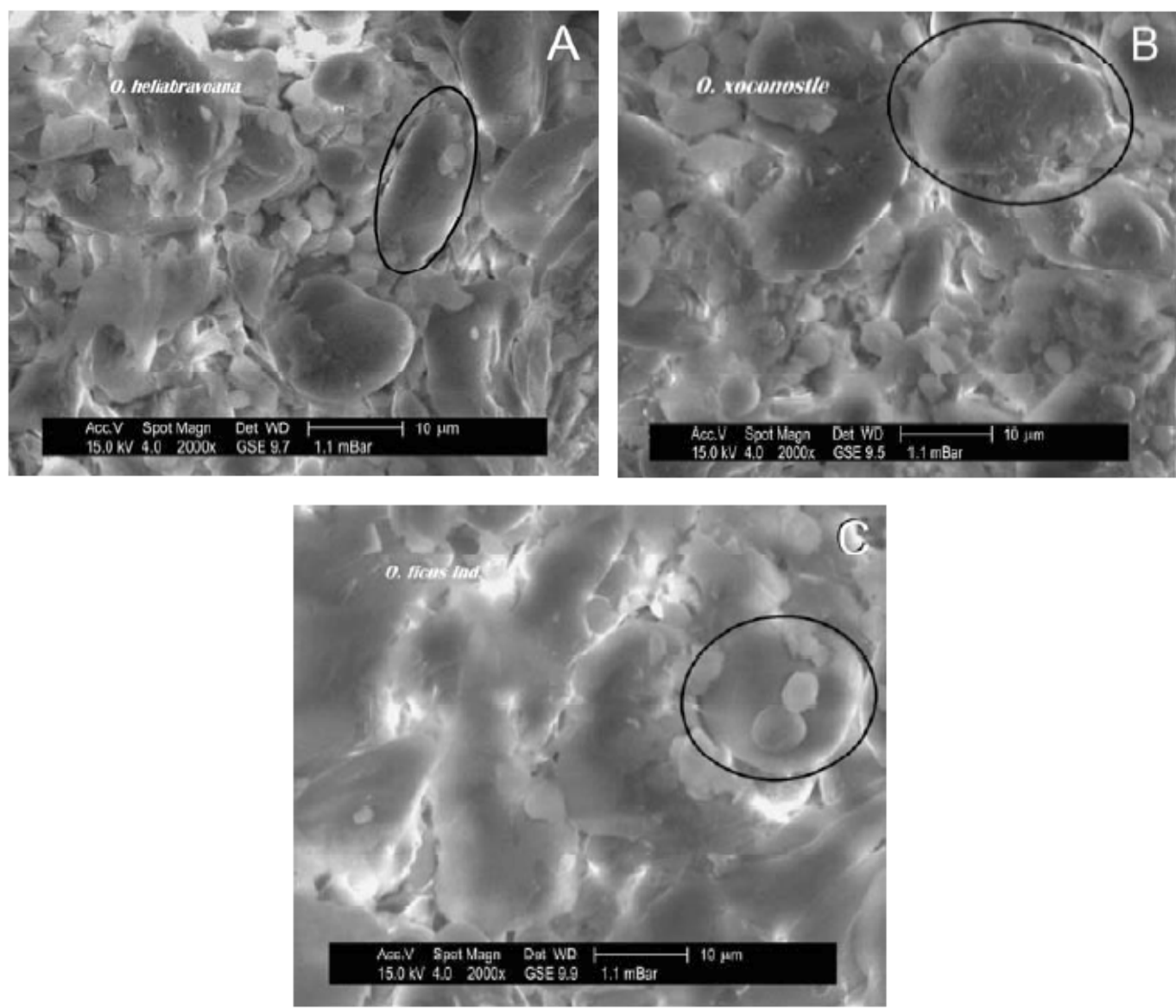

Figure 2. Micrographs of particles of seeds of three species of Opuntia. A) $O$. heliabravoana, in which small granules are observed, B) $O$. xoconostle, with larger granules, and C) $O$. ficus-indica, with granules of relatively uniform size

are associated with the fibers that appear in the extraction and separation of starch.

The seeds of the three species of Opuntia evaluated for their high carbohydrate content, in particular fats and starches, may have nutritional value that justifies their preparation as food products or supplements for human consumption. However, special attention should be paid to the lead content of the seeds, which could represent a disadvantage in this regard. Additionally, the starch granules found in the seeds resemble those reported for cereal grains.

\section{Resumen}

F. Prieto-García, J. Prieto Méndez, O.A. Acevedo Sandoval, A. Román-Gutiérrez y Y. Marmolejo Santillán. 2016. Caracterización química y física de semillas de Opuntia spp. cultivadas en el Estado de Hidalgo, México. Cien. Inv. Agr. 43(1):143-150. Los frutos del nopal (Opuntia spp.) representan un alimento valioso en varios países de América Latina. Por lo general, sus semillas se descartan aunque podrían contener componentes básicos que podrían permitir su utilización como complemento alimenticio o como otro producto conveniente para la industria. El objetivo de este trabajo fue realizar una caracterización física y química de 
semillas de tres especies de Opuntia (O. Heliabravoana, O. xoconostle, y O. ficus-indica) para generar un conocimiento específico de ellas. Los frutos se recogieron en diferentes municipios del Estado de Hidalgo, México, y las semillas extraídas, se secaron y se analizaron. Las semillas mostraron similitud en las características físicas de densidad y dureza a la abrasión, a excepción de pequeñas diferencias. Debido a su tamaño relativo y el volumen, la semilla de $O$. ficus-indica resultó 2,37 veces más voluminoso que la semilla más pequeña ( $O$. heliabravoana) y 1,50 veces mayor que la de $O$. xoconostle. El tamaño y la morfología de los granos fueron similares entre las especies. Debido a su relativamente alto contenido de aceite, fibras, almidones e hidratos de carbono el resultado es interesante para ser evaluado como alimento nutritivo. Sin embargo, en todos ellos se encontró significativamente altas cantidades de plomo, que es un metal no deseable en cualquier alimento.

Palabras clave: Análisis proximal, Cactaceae, metales pesados, microscopio electrónico, nopal, tamaño de partícula, tuna.

\section{References}

AOAC. 2005. Official Methods of Analysis of the Association of Official Analytical Chemist. Volumes I and II. In: K. Herlich (ed.). AOAC International. Minneapolis, $\mathrm{MN}$.

Blanco, M.A., M. de los A. Montero, and M. Fernández. 2000. Composición química de productos alimenticios derivados de trigo y maíz elaborados en Costa Rica. Archivos Latinoamericanos de Nutrición 50: 62-74.

BOE- Boletín Oficial Español (English: Spanish Official Gazette). 1988. Cereales en copos o expandidos. Métodos de análisis. BOE. Madrid, España. 28 pp.

Borrego, E.F., and V.N. Burgos. 1986. El Nopal. Ed. Universidad Autónoma Agraria Antonio Narro. Saltillo, México. 145 pp.

Bravo-Hollis, H. 1991. Las Cactáceas de México. Volumen III. UNAM. México, D.F. 643 pp.

Dendy, DA., and B.J. Dobraszczyk. 2004. Cereales y Productos Derivados. Química y Tecnología. Ed. Acribia. Zaragoza, España. 532 pp.

Normativa Argentina. 2004. Título IV. De los Contaminantes, Párrafo I. De los metales Pesados. Artículo 160. p. 1. Available online at: http:// www.tecnoalimentos.cl/html2/tit04.html (Website accessed: November 2004).

NMX. Norma Mexicana. 2003. Productos alimenticios no industrializados para consumo humano- cereal-cebada maltera (Hordeum vulgare L. y Hordeum distichum L.). Especificaciones y métodos de prueba. Norma NMX-FF-043-SCFI.

Ödön, I.V., and W.S. Tirso. 1985. Química de los Alimentos. Tomo I. Ed. Pueblo y Educación. México. 274 pp.

Ojeda M.C., R.E. Vázquez, and H. Rodríguez. 2010. Establecimiento in vitro de nopal (Opuntia ficusindica). RESPYN Revista Salud Pública y Nutrición (Edición Especial) 5:176-181.

Pere, D. 1999. Métodos Oficiales de Análisis. Cereales, Derivados de Cereales y Cerveza. Edit. Panreac Química. Madrid, España. 88 pp.

Prieto, F., J. Callejas, M.A. Lechuga, J.C. Gaytá, and E. Barrado. 2005a. Acumulación en tejidos vegetales de arsénico proveniente de aguas y suelos de Zimapán estado de Hidalgo México. Bioagro 17:129-135.

Prieto, J., M.A. Méndez, A.D. Román, and F. Prieto. 2005b. Estudio comparativo de características físicoquímicas de cereales Kellogg's. Revista Chilena de Nutrición 32:48-59.

Prieto F.; M.A. Méndez; E. Pérez; S. F. Kerstup, and B.R. Cruz. 2008. Morfología, tamaño y distribución de partículas en semillas de cinco especies del género Opuntia. Universidad y Ciencia 24:159-162.

Scheinvar, L. 1999. Biosistemática de los xoconostles mexicanos y su potencial económico. Memorias del VIII Congreso Nacional y VI Interna- 
cional sobre Conocimiento y Aprovechamiento del Nopal. Univ. Autónoma de San Luis Potosí, México. p. 255-274.

Sharp, P.F. 1987. Wheat and flour studies. Density of wheat as influenced by freezing stage of development, and moisture content. Cereal Chemistry 4:14-46.
Terán Y., D. Navas, D. Petit, E. Garrido, and R. DÀubeterre. 2015. Análisis de las características físico--químicas del fruto de Opuntia ficus-indica (L.) Miller, cosechados en Lara, Venezuela. Revista Iberoamericana de Tecnología Postcosecha 16:69-74. 